\title{
Supplier Selection Using FAHP and FTOPSIS in a Chemical Manufacturing Company
}

\author{
Shelvy Kurniawan ${ }^{1 *}$; Stevanni Cyintia Dewi²; Siska Marisah ${ }^{3}$ \\ ${ }^{1-3}$ Management Department, BINUS Business School Undergraduate Program, \\ Bina Nusantara University \\ Jln. K. H. Syahdan No. 9, Jakarta Barat 11480, Indonesia \\ 'shelvy.kurniawan001@binus.ac.id; 'stevaniecynthia@gmail.com; \\ ${ }^{3}$ siskamarisaa@gmail.com
}

Received: $26^{\text {th }}$ January 2020/ Revised: $26^{\text {th }}$ March 2020/ Accepted: $30^{\text {th }}$ March 2020

How to Cite: Kurniawan, S., Dewi, S. C., \& Marisah, S. (2020). Supplier Selection Using FAHP and FTOPSIS in a Chemical Manufacturing Company. Binus Business Review, 11(2), 115-127. https://doi.org/10.21512/bbr.v11i2.6255

\begin{abstract}
The research aimed to determine the appropriate weight criteria and sub-criteria in selecting the chemical solvent supplier. It was also to recommend the best alternative suppliers using a comparative analysis method of Fuzzy Analytical Hierarchy Process (FAHP) and Fuzzy Technique for Order of Preference by Similarity to Ideal Solution (FTOPSIS). The research was conducted in one of the chemical manufacturing companies in Indonesia. The type of research was descriptive with a quantitative approach that used primary data sources such as questionnaires, interviews, and observations, and secondary data such as books and journals. The criteria studied were cost, quality, delivery, flexibility, supplier profile, and supplier relationship. The results of using FAHP indicate that the criteria with a major influence on the decision making of supplier selection are quality followed by delivery, cost, supplier relationship, flexibility, and supplier profile in sequence. Then, using FTOPSIS, it recommends that the best supplier alternative decision is Supplier A with a weight value of 0,773 and an approved evaluation status. The results have shown that both methods are suitable for supplier selection, particularly in supporting group decision making and modeling uncertainty.
\end{abstract}

Keywords: supplier selection, Fuzzy Analytical Hierarchy Process (FAHP), Fuzzy Technique for Order of Preference by Similarity to Ideal Solution (FTOPSIS)

\section{INTRODUCTION}

Indonesia's economic structure by business in 2017 was still dominated by business fields, namely the manufacturing or industrial sector (Kementerian Perindustrian Republik Indonesia, 2019). The researchers study the company engaged in that industry, which is a chemical manufacturing company. According to interviews with the Operational Manager, the number of products owned by the company certainly requires the company to have several suppliers to meet the needs of raw materials in which each of it has several suppliers. The variety of suppliers and its criteria makes the company face difficulties in choosing the best suppliers to cut expenses and to achieve profit targets. It is necessary to select the right supplier to minimize the comparison of market prices and the difference in the number of raw materials and obtain the quality of raw materials and other aspects that will optimize Supply Chain Management (SCM) in this industry.

The term of SCM was credited to Oliver and Webber in 1982 and was quickly introduced to academia by Jones and Riley in 1987 and Ellram and Cooper in 1990 (Carter, Rogers, \& Choi, 2015). It consists of all parties involved in meeting customer demands directly or indirectly. It does not only involve producers and suppliers, but also transporters, warehouses, retailers, and customers. In every organization, such as a manufacturer, it provides all involved functions in receiving and filling customers' requests. These functions are not limited 
to new product development, marketing, operations, distribution, finance, and customer service (Chopra \& Meindl, 2016). According to Jain, Sangaiah, Sakhuja, Thoduka, and Aggarwal (2018), supplier selection is a strategic decision that companies take as a result of which they identify and evaluate potential suppliers offering high-value products and services. The rapid advances and competition between companies need effective management of the supply chain for gaining more profit. Similarly, Junior, Osiro, and Carpinetti (2014) agreed that supplier selection was one of the most important activities of acquisition as its results had a great impact on the quality of goods and performance of organizations and supply chains. Through supplier selection, it was also possible to anticipate the evaluation of the potential of suppliers to establish a collaborative relationship.

In selecting suppliers, it is necessary to determine the criteria as a material for the selection of alternative suppliers. Supplier selection criteria can form a set of strategic qualifications and operational standards used by buyers to align between external sources and internal goals. The right supplier selection criteria can help guarantee the uncertainty in the supplier's role and the possibility to predict outcomes and responses (Nair, Jayaram, \& Das, 2015). The criteria can vary depending on the type of product or industry being considered (Gurung \& Phipon, 2016). To make accurate supplier selection and appropriate criteria, the company requires methods that can support decision making. One of the methods for decision making is Multi Criteria Decision Making (MCDM). According to Mulliner, Malys, and Maliene (2016), MCDM is a set of methods for evaluating alternatives in terms of numerous conflicting decision criteria. Thus, given a set of alternatives (options) and several decision criteria, the goal of MCDM is to provide a choice, ranking, description, classification, sorting, and order of alternatives from the most preferred to the least preferred option. According to Taylan, Bafail, Abdulaal, and Kalbi (2014), in MCDM problems, the attribute values and the relative weights are usually characterized by a fuzzy number.

If the value assigned is 0 , the element does not belong to the set (it has no membership). If the value assigned is 1, the element belongs entirely to the set (it has no membership). Finally, if the value lies within the interval $[0,1]$, the element has a certain degree of membership (it belongs partially to the fuzzy set). Then, a fuzzy set contains elements that have different degrees of membership in it. The main characteristic of fuzzy is the grouping of individuals into classes that do not have sharply defined boundaries. Based on Junior et al. (2014), fuzzy set theory combined with MCDM methods has been extensively used to deal with uncertainty in the supplier selection decision process, since it provides a suitable language to handle imprecise criteria and to integrate the analysis of qualitative and quantitative factors. From many methods of MCDM, the researchers choose the most popular methods of supplier selection. It is fuzzy set theory combined with MCDM methods such as Analytical Hierarchy Process (AHP) and Technique for Order of Preference by Similarity to Ideal Solution (TOPSIS).

Fuzzy Analytical Hierarchy Process (FAHP) is the perfecting method of the AHP method. It covers the weaknesses that exist in the AHP method. According to Thomas L. Satty in Devi and Wardhana (2018), AHP is a method used in the decision-making process of complex problems. Problems solved using the AHP method are said to be complex if the structure of the problem is inaccurate. So, the input used to solve this problem is human thought. The AHP method breaks a situation into parts and organizes these parts or variables into a hierarchical arrangement.

Meanwhile, TOPSIS was first introduced by Yoon and Hwang in 1981. They developed the TOPSIS method based on the concept that the alternative chosen had to have the shortest distance from the positive-ideal solution and the longest distance from the negative ideal solution ( $\mathrm{Lu}$, Zhang, Ruan, \& $\mathrm{Wu}, 2007)$. According to Ertugrul and Karakasoglu in Chatterjee and Stević (2019), by using FAHP and Fuzzy Technique for Order of Preference by Similarity to Ideal Solution (FTOPSIS), uncertainty and vagueness from subjective perception and the experiences of decision-maker can be adequately represented, and it can reacha more effective decision. FAHP is employed to determine the relative importance of the selected criteria. Then, based on the points given to the alternatives in different selected criteria by the personnel interviewed, FTOPSIS is used to rank the competing suppliers (Sultana, Ahmed \& Azeem, 2015).

Özbek (2015) suggested that the supplier selection model was developed to help managers of a company make decisions in selecting suppliers. The researcher used FTOPSIS. The results showed that the most appropriate supplier was supplier B. However, there was no significant difference between suppliers, especially Suppliers A and C. The company could choose to work with these three suppliers, but Supplier $\mathrm{B}$ was the top priority.

Moreover, Junior et al. (2014) analyzed comparative studies of FAHP and FTOPSIS methods applied to supplier selection. Despite the large number of articles proposing the use of FAHP and FTOPSIS, they said there were no comparative studies of these two methods applied to supplier selection. The results revealed that both methods were suitable for supplier selection, particularly to support group decision making and model uncertainty. However, the comparative analysis in this research had shown that the FTOPSIS method suited the supplier selection regarding changes of alternatives and criteria, agility and number of criteria, and alternative suppliers.

Li et al. (2019) studied the distribution network of supplier selection with FAHP and TOPSIS. They said choosing the proper suppliers for distribution network commodities was very important. Due to the stringent requirement on the safe and normal 
operation, the suppliers for distribution network commodities were assessed by various criteria. They found out that cost, quality, delivery, and service were the most important criteria.

Similarly, Karabayir, Botsali, Kose, and Cevikcan (2019) analyzed the supplier selection method in a construction company in Turkey using the FAHP and FTOPSIS. In the past, the price list was sufficient for choosing the supplier, but nowadays, selection depended on numerous criteria such as price, quality, delivery, variety, and warranty. Later on, they indicated six commonly used criteria for supplier evaluations. The criteria obtained were flexibility, quality, price, relationship, profile, and delivery. The result showed that the value of criteria was different based on both methods, but the rankings were similar. The ranking of criteria was the price, delivery, relationship, profile, flexibility, and quality, respectively, according to the results of FTOPSIS.

Meanwhile, according to FAHP, the criteria weights were sorted to price, delivery, profile, relationship, flexibility, and quality. The diversity in relationship and profile criteria weights was mainly due to the differences in algorithms. For the sequence of alternatives results, the first preferred supplier was A2, according to both methods.

Different from the others, Nazari-Shirkouhi, Miri-Nargesi, and Ansarinejad (2017) examined project selection with FAHP and FTOPSIS. They proposed a structured method for outsourcing information systems for project selection using FAHP and FTOPSIS analysis with seven criteria and five alternative decisions. To accommodate the criteria, FAHP was chosen to get the relative weights of the criteria. It was found that FTOPSIS was more practical for ranking information systems in terms of their overall performance concerning several criteria. In addition to these two methods, several methods that had been extended in the fuzzy environment could be used to compare the results used.

Chen, Chou, Luu, and Yu (2016) said that in sorting the importance of the FAHP criteria, it had a lower complexity time compared to other fuzzy sets methods. They showed that the calculations were easier. In accordance with the previous statement, Junior et al. (2014) also revealed that FAHP was an efficient tool for dealing with data inconsistencies involved in deciding the preferences of different decision variables. As for the FTOPSIS, Simić, Kovačević, Svirčević, and Simić (2017) stated that FTOPSIS had no limitation of increasing the number of alternative suppliers. So, any increase in the number of alternative suppliers would not affect the calculation results, and FTOPSIS delivered more consistent results. However, alternative input was not optimal.

Based on some previous research, the research focuses on measuring the weight of criteria and providing a priority level for alternative suppliers using FAHP. The research also evaluates a priority level based on the distance to the ideal solution, both positive and negative using FTOPSIS. The research focuses on a chemical manufacturing company in Indonesia. It is located at Cakung, East Jakarta City. The most top-selling product is called as OD 661. Figure 1 displays the three most purchased materials, which are raw materials for OD 661 products. The criteria used are the combination of the adaptation from several previous researchers that suit the needs of the company. Those criteria are summarized in Table 1.

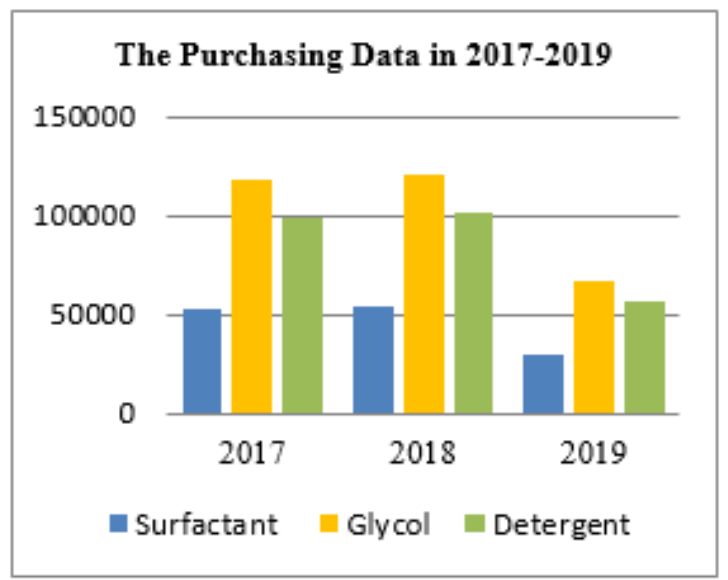

Figure 1 The Purchasing data in 2017-2019 (Source: The Researchers, 2019)

Table 1 Supplier Selection Criteria in Chemical Manufacturing Company

\begin{tabular}{ll}
\hline Criteria & Definition \\
\hline Cost & $\begin{array}{l}\text { Supplier's aptitude to offer competitive } \\
\text { prices and payment methods }\end{array}$ \\
Quality & $\begin{array}{l}\text { Supplier's aptitude to provide qualified } \\
\text { products based on company needs }\end{array}$ \\
Delivery & $\begin{array}{l}\text { Supplier's aptitude to deliver materials } \\
\text { safely to the destination }\end{array}$ \\
Flexibility & $\begin{array}{l}\text { Supplier's flexibility on adjusting changes } \\
\text { of the order request }\end{array}$ \\
Supplier Profile & $\begin{array}{l}\text { Historical records about the supplier } \\
\text { Supplier }\end{array}$ \\
Relationship & $\begin{array}{l}\text { Supplier's aptitude to maintain relationship } \\
\text { and provide assistance during or after } \\
\text { purchasing items }\end{array}$ \\
\hline
\end{tabular}

(Source: Junior et al., 2014; Chen et al., 2016; Hajar, 2016)

\section{METHODS}

A descriptive quantitative approach is chosen as the research method, and the time horizon is crosssectional with a chemical manufacturing company as the unit of analysis. The research uses both primary and secondary data. The primary data are from questionnaires, interviews, and observations. 
Interviews are conducted by the researchers with two respondents (Operational Manager and Purchasing Manager) as an expert in the company. Meanwhile, the secondary data used are the pages of government publications, previous literature review, data of purchasing raw materials, books, and journals.

The research uses a comparative method between FAHP and FTOPSIS. In the analysis process, both methods have some similarities on the steps. First, it is specifying the supplier selection criteria and subcriteria indicators. Second, the researchers interview the responsible source in the purchasing department in the company to collect alternative suppliers. Third, it is making the questionnaire that contains the assessment weights for criteria and sub-criteria and gives it to the responsible source. Fourth, the researchers calculate the results from the questionnaire for the weight of criteria, sub-criteria, and alternatives. Last, from the result, researchers receive the final level of priorities, conclusions, and suggestions.

\section{RESULTS AND DISCUSSIONS}

The researchers examine the best-selling product of the company that is OD 661 consisting of three chemical compounds. Each compound has two alternative suppliers. The compounds are surfactant, glycol, and detergent. The researchers decide to calculate these compounds because they are the most frequently purchased by the company. In this research, the surfactant will be the calculation example. The calculation is divided into FAHP and FTOPSIS. In

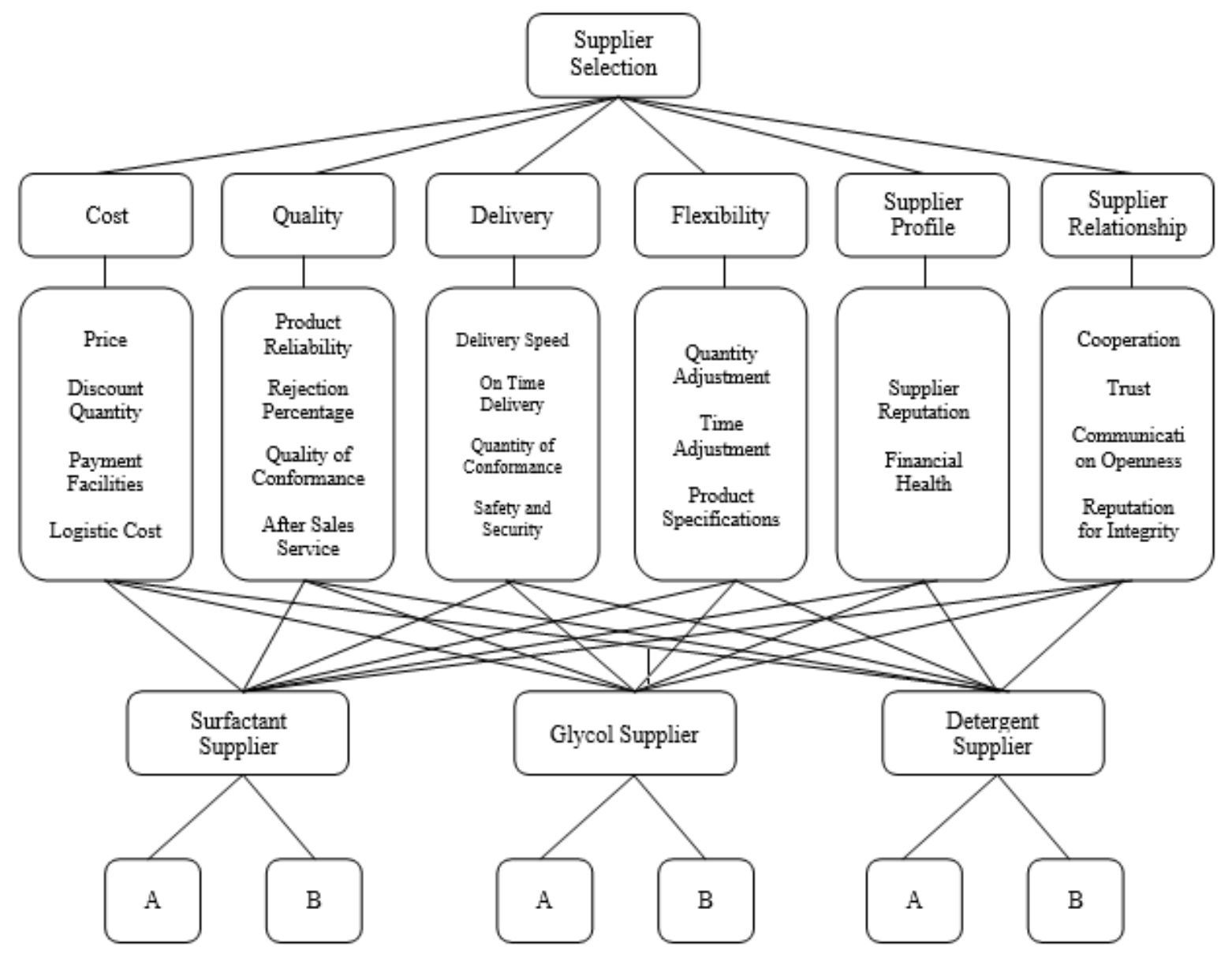

Figure 2 FAHP Criteria Hierarchy Structure

(Source: The Researchers, 2019) 
FAHP, the first step is to create a hierarchical model based on criteria, sub-criteria, and alternatives as research material. It is shown in Figure 2.

The second step of FAHP is to enter the weight of the questionnaire into the fuzzy scale. Then, the researchers convert it into the Triangular Fuzzy Number (TFN), which is followed by pairwise comparisons. Tables 2 to 4 show the fuzzy scale, TFN used, and the pairwise comparison between criteria sequently.

Table 2 Fuzzy Scale

\begin{tabular}{|c|c|c|}
\hline $\begin{array}{l}\text { Intensity of } \\
\text { Importance }\end{array}$ & Definition & Explanation \\
\hline 1 & Equal importance & $\begin{array}{l}\text { Two activities } \\
\text { contribute equally to } \\
\text { the objective. }\end{array}$ \\
\hline 3 & $\begin{array}{l}\text { Weak importance of } \\
\text { one over the other }\end{array}$ & $\begin{array}{l}\text { Experience and } \\
\text { judgment slightly favor } \\
\text { one over the others. }\end{array}$ \\
\hline 5 & $\begin{array}{l}\text { Essential or strong } \\
\text { importance }\end{array}$ & $\begin{array}{l}\text { Activity is strongly } \\
\text { favored, and its } \\
\text { dominance is } \\
\text { demonstrated in } \\
\text { practice. }\end{array}$ \\
\hline 7 & $\begin{array}{l}\text { Demonstrated } \\
\text { importance }\end{array}$ & $\begin{array}{l}\text { The evidence favoring } \\
\text { over another is the } \\
\text { highest possible order } \\
\text { of affirmation. }\end{array}$ \\
\hline 9 & $\begin{array}{l}\text { Absolute } \\
\text { importance }\end{array}$ & $\begin{array}{l}\text { When compromise is } \\
\text { needed }\end{array}$ \\
\hline $2,4,6,8$ & Intermediate values & \\
\hline
\end{tabular}

(Source : Ouma, Opudo, \& Nyambenya, 2015)

Table 3 TFN Scale

\begin{tabular}{clc}
\hline $\begin{array}{c}\text { Fuzzy } \\
\text { Number }\end{array}$ & Linguistic & $\begin{array}{l}\text { The scale of the } \\
\text { fuzzy number }\end{array}$ \\
\hline 1 & Equal & $(1,1,1)$ \\
2 & Weak advantage & $(1,2,3)$ \\
3 & Not bad & $(2,3,4)$ \\
4 & Preferable & $(3,4,5)$ \\
5 & Good & $(4,5,6)$ \\
6 & Fairly good & $(5,6,7)$ \\
7 & Very good & $(6,7,8)$ \\
8 & Absolute & $(7,8,9)$ \\
9 & Perfect & $(8,9,10)$ \\
\hline
\end{tabular}

(Source: Huynh, Nguyen, Nguyen, \& Nguyen, 2018)

The third step of FAHP analysis is to calculate the factors of paired comparison matrices. Those have been converted into TFN using the geometric mean calculation method adapted from Huynh et al. (2018). The equations are as follows:

$$
\begin{aligned}
& \mathrm{R}_{\mathrm{i}}=\left(\tilde{a}_{\mathrm{i} 1} \times \tilde{a}_{\mathrm{i} 2} \times \tilde{a}_{\mathrm{i} 3} \times \ldots \times \tilde{a}_{\mathrm{in}}\right)^{1 / \mathrm{n}} \\
& a_{\mathrm{ij}}=\left(\tilde{a}_{\mathrm{ij}} \times \tilde{a}_{\mathrm{ij}} \times \tilde{a}_{3 \mathrm{ij}} \times \ldots \times \tilde{a}_{\mathrm{ij}}\right) \\
& \text { Reverse }=\left(\frac{1}{u}, \frac{1}{m}, \frac{1}{l}\right)
\end{aligned}
$$

Based on the result in Table 4 (see Appendices), the researchers convert the value to Table 5. Is the reverse value which is calculated using Equation (3). The example is shown in the following calculation using Equation (1).

$$
\begin{aligned}
& \mathrm{R}_{\text {cost }}=[(1,1,1) \times(6,7,8) \times(1,1,1) \times(8,9,9) \times(1,1,1) \\
& \times(1,1,1)]^{1 / 3}=(1,074,1,080,1,082)
\end{aligned}
$$

Table 5 The Results of Pairwise Comparison Weight between Criteria

\begin{tabular}{lccc}
\hline Criteria $(\mathbf{M})$ & \multicolumn{3}{c}{$\mathbf{r}_{\mathbf{i}}(\mathbf{l}, \mathbf{m}, \mathbf{u})$} \\
\hline Cost $\left(\mathrm{r}_{1}\right)$ & 1,074 & 1,080 & 1,082 \\
Quality $\left(\mathrm{r}_{2}\right)$ & 1,339 & 1,390 & 1,415 \\
Delivery $\left(\mathrm{r}_{3}\right)$ & 1,133 & 1,185 & 1,234 \\
Flexibility $\left(\mathrm{r}_{4}\right)$ & 0,777 & 0,794 & 0,821 \\
Supplier Profile $\left(\mathrm{r}_{5}\right)$ & 0,738 & 0,752 & 0,775 \\
Supplier Relationship & 0,794 & 0,818 & 0,851 \\
$\left(\mathrm{r}_{6}\right)$ & & & \\
\hline TOTAL & 5,854 & 6,018 & 6,177 \\
\hline Reverse & 0,162 & 0,166 & 0,171 \\
\hline
\end{tabular}

(Source : The Researchers, 2019)

The fourth step is converting the value in Table 5 to the value in Table 6 . The value in Table 6 is the relative fuzzy weight. The equations and the example of the relative fuzzy weight of each criterion $\left(\mathrm{w}_{\mathrm{i}}\right)$ are as follows:

$$
\begin{aligned}
& \widetilde{w}_{\mathrm{i}}=\left(L w_{\mathrm{i}}, M w_{\mathrm{i}}, U w_{\mathrm{i}}\right) \\
& \widetilde{W}_{\mathrm{i}}=\tilde{r}_{\mathrm{i} 1} \times\left(\tilde{r}_{1}+\tilde{r}_{2}+\tilde{r}_{3}+\cdots+\tilde{r}_{\mathrm{n}}\right)^{-1} \\
& \mathrm{~W}_{\text {cost }}=\mathrm{r}_{\text {cost }}(1, \mathrm{~m}, \mathrm{u}) \times\left(\sum \sum \mathrm{r}_{\text {cost }}\right)^{-1} \\
& =(0,1074,1,080,1,082) \times\left(\frac{1}{6,177}, \frac{1}{6,018}, \frac{1}{5,854}\right) \\
& =0,173,0,179,0,186
\end{aligned}
$$

The fifth step is to calculate normalized weights as shown in Table 7. The normalization weight determines the pairwise comparison matrix ranking of each comparison. The highest normalization weights are taken for the final decision. The normalized weightsare calculated by using the following formula:

$$
B N P_{\mathrm{wi}}=[(U w i-L w i)+(M w i-L w i)] / 3+L w i
$$


Where,

$\mathrm{L}=$ the lower value of the $\mathrm{w}_{\mathrm{i}}$

$\mathrm{M}=$ the medium value (middle) of $\mathrm{w}_{\mathrm{i}}$

$\mathrm{U}=$ the upper value of the $\mathrm{w}_{\mathrm{i}}$

Table 6 The Results of Calculation of Wi between Criteria

\begin{tabular}{lccc}
\hline Criteria & \multicolumn{3}{c}{$\mathbf{w}_{\mathbf{i}}$} \\
\hline Cost & 0,173 & 0,179 & 0,186 \\
Quality & 0,216 & 0,231 & 0,246 \\
Delivery & 0,183 & 0,197 & 0,211 \\
Flexibiliy & 0,124 & 0,132 & 0,141 \\
Spplier Profile & 0,118 & 0,125 & 0,133 \\
Supplier & 0,127 & 0,136 & 0,146 \\
Relationship & & & \\
\hline
\end{tabular}

(Source : The Researchers, 2019)

Table 7 The Results of Calculation of Normalized Weight between Criteria

\begin{tabular}{lc}
\hline Criteria & Normalized Weight \\
\hline Cost & 0,179 \\
Quality & 0,231 \\
Delivery & 0,197 \\
Flexibility & 0,132 \\
Supplier Profile & 0,125 \\
Supplier Relationship & 0,136 \\
\hline
\end{tabular}

(Source: The Researchers, 2019)

Based on the steps mentioned, the final result of the FAHP in the supplier selection process of the surfactant is in Tables 8-10. From the results of the comparison of importance between the criteria using the FAHP in Table 8 , it is found that the quality has the highest importance level with a weight of 0,231 . Then, it is followed by delivery $(0,197)$, cost $(0,179)$, supplier relationship $(0,136)$, flexibility $(0,132)$, and supplier profile $(0,125)$.

Table 8 The Results of FAHP on the Criteria

\begin{tabular}{lcc}
\hline Criteria & $\begin{array}{c}\text { Normalized } \\
\text { Weights }\end{array}$ & Rank \\
\hline Cost & 0,179 & 3 \\
Quality & 0,231 & 1 \\
Delivery & 0,197 & 2 \\
Flexibility & 0,132 & 5 \\
Supplier Profile & 0,125 & 6 \\
Supplier Relationship & 0,136 & 4 \\
\hline
\end{tabular}

(Source: The Researchers, 2019)
Table 9 The Results of FAHP on Sub-Criteria

\begin{tabular}{|c|c|c|c|}
\hline Criteria & $\begin{array}{l}\text { Sub-criteria } \\
\text { (Priority 1) }\end{array}$ & $\begin{array}{l}\text { Sub-criteria } \\
\text { (Priority 2) }\end{array}$ & $\begin{array}{l}\text { Sub-criteria } \\
\text { (Priority 3) }\end{array}$ \\
\hline Cost & Price & $\begin{array}{l}\text { Discount } \\
\text { quantity }\end{array}$ & Logistic cost \\
\hline Quality & $\begin{array}{l}\text { After-sale } \\
\text { service } \\
\text { quality }\end{array}$ & $\begin{array}{l}\text { Rejection } \\
\text { percentage }\end{array}$ & $\begin{array}{l}\text { Product } \\
\text { reliability }\end{array}$ \\
\hline Delivery & $\begin{array}{l}\text { Safety and } \\
\text { security }\end{array}$ & $\begin{array}{l}\text { Quantity of } \\
\text { conformance }\end{array}$ & $\begin{array}{l}\text { On-time } \\
\text { delivery }\end{array}$ \\
\hline Flexibility & $\begin{array}{l}\text { Quantity } \\
\text { adjustment }\end{array}$ & $\begin{array}{l}\text { Product } \\
\text { specifications }\end{array}$ & $\begin{array}{l}\text { Time } \\
\text { adjustment }\end{array}$ \\
\hline $\begin{array}{l}\text { Supplier } \\
\text { profile }\end{array}$ & $\begin{array}{l}\text { Supplier } \\
\text { reputation }\end{array}$ & Financial health & - \\
\hline $\begin{array}{l}\text { Supplier } \\
\text { relationship }\end{array}$ & Trust & Cooperation & $\begin{array}{l}\text { Reputation } \\
\text { for integrity }\end{array}$ \\
\hline
\end{tabular}

(Source: The Researchers, 2019)

The results of the importance comparison between sub-criteria using the FAHP in Table 9 obtain the three best sub-criteria of each criterion. In the cost criteria, the first priority is the price. Then, the second and third priorities are the quantity and logistic cost respectively. For the quality criteria, the order is after-sale service, rejection percentage, and product reliability. Then, in the delivery, there are safety and security, the quantity of conformance, and on-time delivery. Next, for the flexibility criteria, the order is quantity adjustment, product specifications, and time adjustment. In the supplier profile criteria, there are supplier reputation and financial health. Last, the supplier relationship criteria have trust, cooperation, and reputation for integrity.

Based on Table 10, the results of the FAHP show that Supplier A is the best supplier with a value of 23,157 for surfactant. The difference of 1,299 is higher than Supplier B. To summarize the calculation results from the FAHP, it has found the prioritized criteria, sub-criteria, and the best alternative supplier. Thus, the researchers can recommend the supplier, criteria, and sub-criteria to be considered by the company in the process of supplier selection for surfactant.

Next, it is FTOPSIS application. The first step of using FTOPSIS is to input the weight of the questionnaires into the TFN based on the linguistic scale and the importance criteria from the questionnaires. The results are shown in Tables 11-13.

Table 11 shows the linguistic scale for evaluating the rank of interest criteria. VL is denoted by TFN value of 0,$0 ; 0,0$; and 0,25 . For $M$, it is denoted by TFN value of 0,$0 ; 0,25$; and 0,50 . For $I$, it is shown by TFN value of 0,$25 ; 0,50$; and 0,75 . For VI, it is denoted by the TFN value of 0,$50 ; 0,75$; and 1,0 . Last, in AI, there is the TFN value of 0,$75 ; 1,0$; and 1,0 . Table 12 presents the linguistic scale to evaluate alternative supplier ratings. Similar to Table 11, it shows the TFN values of each linguistic scale. For example, VL is denoted by 0,$0 ; 0,0$; and 2,5 . 
Table 10 FAHP of Surfactant Suppliers

\begin{tabular}{lcc}
\hline Sub-Criteria & \multicolumn{2}{c}{ Supplier } \\
& A & B \\
\hline Price & 0,761 & 1,321 \\
Discount quality & 1,383 & 1,470 \\
Payment facilities & 0,724 & 1,423 \\
Logistic cost & 1,000 & 1,000 \\
Product realibility & 1,000 & 1,000 \\
Rejection percentage & 1,321 & 0,761 \\
Quality of conformance & 1,383 & 0,734 \\
After-sale service quality & 0,730 & 1,470 \\
Delivery speed & 1,000 & 1,000 \\
On time delivery & 0,747 & 1,349 \\
Quantity of conformance & 0,730 & 1,470 \\
Safety and security & 1,533 & 0,839 \\
Quantity adjustment & 1,423 & 0,724 \\
Time adjustment & 1,470 & 0,730 \\
Product spesifications & 1,383 & 0,734 \\
Supplier reputation & 1,000 & 1,000 \\
Financial health & 1,470 & 0,730 \\
Cooperation & 1,000 & 1,000 \\
Trust & 0,839 & 1,533 \\
Communication openness & 1,533 & 0,839 \\
Reputation for integrity & $\mathbf{2 3 , 1 5 7}$ & $\mathbf{2 1 , 8 5 8}$ \\
\hline Total & & \\
\hline & &
\end{tabular}

(Source: The Researchers, 2019)

Table 11 Linguistic Scale for Evaluating Rank of Interest Criteria

\begin{tabular}{ll}
\hline Linguistic terms & $\begin{array}{l}\text { Triangular Fuzzy Number } \\
\text { (TFN) }\end{array}$ \\
\hline Little important (VL) & $(0,0 ; 0,0 ; 0,25)$ \\
Moderately important (M) & $(0,0 ; 0,25 ; 0,50)$ \\
Important (I) & $(0,25 ; 0,50 ; 0,75)$ \\
Very Important (VI) & $(0,50 ; 0,75 ; 1,0)$ \\
Absolutely Important (AI) & $(0,75 ; 1,0 ; 1,0)$ \\
\hline
\end{tabular}

(Source: Junior et al., 2014)

Table 12 Linguistic Scale to Evaluate

Alternative Supplier Ratings

\begin{tabular}{ll}
\hline Linguistic terms & $\begin{array}{l}\text { Triangular Fuzzy Number } \\
\text { (TFN) }\end{array}$ \\
\hline Very Low (VL) & $(0,0 ; 0,0 ; 2,5)$ \\
Low (L) & $(0,0 ; 2,5 ; 5,0)$ \\
Good (G) & $(2,5 ; 5,0 ; 7,5)$ \\
High (H) & $(5,0 ; 7,5 ; 10,0)$ \\
Excellent (EX) & $(7,5 ; 10,0 ; 10,0)$ \\
\hline
\end{tabular}

(Source: Junior et al., 2014)
Table 13 Importance of Criteria from Questionnaire

\begin{tabular}{ccc}
\hline Criteria & Respondent 1 & Respondent 2 \\
\hline C1 & AI & AI \\
C2 & VI & I \\
C3 & I & MI \\
C4 & I & VI \\
Q1 & AI & AI \\
Q2 & AI & VI \\
Q3 & VI & I \\
Q4 & I & I \\
D1 & AI & VI \\
D2 & VI & VI \\
D3 & I & I \\
D4 & VI & AI \\
F1 & VI & AI \\
F2 & VI & AI \\
F3 & I & VI \\
SP1 & I & VI \\
SP2 & I & AI \\
SR1 & I & VI \\
SR2 & VI & AI \\
SR3 & VI & VI \\
SR4 & I & \\
\hline & & \\
\hline & I & \\
\hline
\end{tabular}

(Source: Junior et al., 2014)

The first step that must be done is to sum the results of the questionnaire data comparison between the criteria and sub-criteria with the alternative suppliers. Table 13 is a recapitalization of the questionnaires for the importance of the criteria. The same summary is done in the alternative supplier questionnaires.

The second step of using FTOPSIS is to change the questionnaire data that have been recapitulated into a fuzzy scale. The results can be seen in Table 14 . The weight of the questionnaire is converted into TFN based on Table 11. The number is based on the weight of the questionnaire. In Table 14, it can be seen that the criteria for $\mathrm{C} 1$ in respondent 1 obtain the value of 0,$75 ; 1,00 ;$ and 1,00 . According to the recapitulation in Table 13, the $\mathrm{C} 1$ criteria in respondent 1 is AI. Then, for alternative supplier conversion, it can be seen from the recapitulation of the questionnaire with fuzzy scale weights based on Table 12. For example, if Supplier A has good questionnaire weight (G), based on Table 12, weights of G fuzzy scale are 2,5; 5,0; and 7,5. 
Table 14 The Results of Conversion Weight of the Importance of Criteria from Questionnaire into TFN

\begin{tabular}{ccccccc}
\hline \multicolumn{7}{c}{ Fuzzy number of criteria } \\
Criteria & \multicolumn{3}{c}{ Respondent 1 } & \multicolumn{3}{c}{ Respondent 2} \\
\hline C1 & 0,75 & 1,00 & 1,00 & 0,75 & 1,00 & 1,00 \\
C2 & 0,50 & 0,75 & 1,00 & 0,25 & 0,50 & 0,75 \\
C3 & 0,25 & 0,50 & 0,75 & 0,00 & 0,25 & 0,50 \\
C4 & 0,25 & 0,50 & 0,75 & 0,50 & 0,75 & 1,00 \\
Q1 & 0,75 & 1,00 & 1,00 & 0,75 & 1,00 & 1,00 \\
Q2 & 0,75 & 1,00 & 1,00 & 0,50 & 0,75 & 1,00 \\
Q3 & 0,50 & 0,75 & 1,00 & 0,25 & 0,50 & 0,75 \\
Q4 & 0,25 & 0,50 & 0,75 & 0,25 & 0,50 & 0,75 \\
D1 & 0,75 & 1,00 & 1,00 & 0,50 & 0,75 & 1,00 \\
D2 & 0,50 & 0,75 & 1,00 & 0,50 & 0,75 & 1,00 \\
D3 & 0,25 & 0,50 & 0,75 & 0,25 & 0,50 & 0,75 \\
D4 & 0,50 & 0,75 & 1,00 & 0,75 & 1,00 & 1,00 \\
F1 & 0,50 & 0,75 & 1,00 & 0,75 & 1,00 & 1,00 \\
F2 & 0,50 & 0,75 & 1,00 & 0,75 & 1,00 & 1,00 \\
F3 & 0,25 & 0,50 & 0,75 & 0,50 & 0,75 & 1,00 \\
SP1 & 0,25 & 0,50 & 0,75 & 0,50 & 0,75 & 1,00 \\
SP2 & 0,25 & 0,50 & 0,75 & 0,75 & 1,00 & 1,00 \\
SR1 & 0,25 & 0,50 & 0,75 & 0,50 & 0,75 & 1,00 \\
SR2 & 0,50 & 0,75 & 1,00 & 0,75 & 1,00 & 1,00 \\
SR3 & 0,50 & 0,75 & 1,00 & 0,50 & 0,75 & 1,00 \\
SR4 & 0,25 & 0,50 & 0,75 & 0,25 & 0,50 & 0,75 \\
\hline & & & & & &
\end{tabular}

(Source: The Researchers, 2019)

Then, for alternative supplier conversion, it is seen from the recapitulation of questionnaires with fuzzy scale weights based on Table 15. It is the result of the calculation of criteria weight (Wij). The point of 1 means it is filled with the lowest weight value by respondents 1 and 2 . Then, the point of $\mathrm{m}$ implies it is medium. Moreover, the point of $u$ shows it has the biggest weight of respondents 1 and respondent 2 . The third step of FTOPSIS is to calculate the weight of sub-criteria $\left(\mathrm{W}_{\mathrm{j}}\right)$ by using the following formula:

$$
\widetilde{w}_{\mathrm{j}}=\frac{1}{k}\left[\widetilde{w}_{\mathrm{j}}+\widetilde{w}_{\mathrm{j}}^{2}+\ldots+\widetilde{w}_{\mathrm{j}}^{k}\right]
$$

The fourth step of FTOPSIS is to calculate the combination matrix of respondents 1 and 2 using Equation (10). In line with the explanation Table 15 , Table 16 is the result of a matrix combination formulation. The point of 1 means the lowest weight value of respondent 1 and 2 . Then, the point of $m$ implies it is medium using Equation (11). Moreover, the point of $\mathrm{u}$ shows it has the biggest weight of respondents 1 and 2 .

$$
\tilde{x}_{\mathrm{ij}}=\frac{1}{k}\left[\tilde{x}_{\mathrm{ij}}{ }^{1}+\tilde{x}_{\mathrm{ij}}{ }^{2}+\ldots+\tilde{x}_{\mathrm{j}}^{\mathrm{k}}\right]
$$

Table 15 The Result of $\mathrm{W}_{\mathrm{j}}$ Formulation

\begin{tabular}{cccc}
\hline \multicolumn{4}{c}{ The weight } \\
\hline C1 & 0,75 & 1,00 & U \\
\hline C2 & 0,25 & 0,63 & 1,00 \\
C3 & 0,00 & 0,38 & 0,75 \\
C4 & 0,25 & 0,63 & 1,00 \\
Q1 & 0,75 & 1,00 & 1,00 \\
Q2 & 0,50 & 0,88 & 1,00 \\
Q3 & 0,25 & 0,63 & 1,00 \\
Q4 & 0,25 & 0,50 & 0,75 \\
D1 & 0,50 & 0,88 & 1,00 \\
D2 & 0,50 & 0,75 & 1,00 \\
D3 & 0,25 & 0,50 & 0,75 \\
D4 & 0,50 & 0,88 & 1,00 \\
F1 & 0,50 & 0,88 & 1,00 \\
F2 & 0,50 & 0,88 & 1,00 \\
F3 & 0,25 & 0,63 & 1,00 \\
SP1 & 0,25 & 0,63 & 1,00 \\
SP2 & 0,25 & 0,75 & 1,00 \\
SR1 & 0,25 & 0,63 & 1,00 \\
SR2 & 0,50 & 0,88 & 1,00 \\
SR3 & 0,50 & 0,75 & 1,00 \\
SR4 & 0,25 & 0,50 & 0,75 \\
\hline & &
\end{tabular}

(Source: The Researchers, 2019)

To convert the value in Table 16, the next step of FTOPSIS is to calculate normalized fuzzy decision matrix $\left(\mathrm{r}_{\mathrm{ij}}\right)$. The result of normalized fuzzy decision matrix is shown in Table 17. The normalized fuzzy decision is calculated by using the following formula.

$$
\begin{aligned}
& \tilde{R}=\left[\tilde{r}_{\mathrm{ij}}\right]_{\mathrm{m} \times \mathrm{n}} \\
& \tilde{r}_{\mathrm{ij}}=\left(l_{\mathrm{ij}} / \mathrm{u}_{\mathrm{j}}^{+}, m_{\mathrm{ij}} / \mathrm{u}_{\mathrm{j}}^{+}, u_{\mathrm{ij}} / \mathrm{u}_{\mathrm{j}}^{+}\right) \\
& \mathrm{u}^{+}=\max _{\mathrm{i}} \mathrm{u}_{\mathrm{ij}}(\text { benefit criteria }) \\
& \tilde{r}_{\mathrm{ij}}=\left(l_{\mathrm{j}}^{-} / \mathrm{u}_{\mathrm{ij}}, l_{\mathrm{j}} / \mathrm{m}_{\mathrm{ij}}, l_{\mathrm{j}} / 1_{\mathrm{ij}}\right) \\
& \mathrm{l}^{-}=\max _{\mathrm{i} \mathrm{ij}}(\operatorname{cost} \text { criteria })
\end{aligned}
$$

Before calculating the $r_{i j}$, researchers first identify each criterion with the benefit criteria and cost criteria categories. After the identification, the calculation is done. The $\mathrm{u}_{\mathrm{ci}}{ }^{+}$of 10,0 is obtained from the largest number of fuzzy numbers $\mathrm{C} 1$. The example of the calculation is described as follows:

$$
\begin{aligned}
\mathrm{rC} 1(\text { supplier } \mathrm{A}) & =\left(\frac{l c 1}{u+}, \frac{m c 1}{u+}, \frac{u c 2}{u+}\right) \\
& =\left(\frac{5,0}{10,0}, \frac{8,75}{10,0}, \frac{10,0}{10,0}\right) \\
& =(0,50 ; 0,88 ; 1,00)
\end{aligned}
$$


Table 16 The Result of $\mathrm{X}_{\mathrm{ij}}$ Formulation

Combination matrix (Xij) of $\mathrm{l}, \mathrm{m}$, and $\mathrm{u}$

\begin{tabular}{|c|c|c|c|c|c|c|}
\hline \multirow{3}{*}{ Criteria } & \multicolumn{6}{|c|}{ Supplier } \\
\hline & \multicolumn{3}{|c|}{$\mathbf{A}$} & \multicolumn{3}{|c|}{ B } \\
\hline & $\mathrm{L}$ & $\mathrm{M}$ & $\mathrm{U}$ & $\mathrm{L}$ & $\mathrm{M}$ & $\mathrm{U}$ \\
\hline $\mathrm{C} 1$ & 5,00 & 8,75 & 10,00 & 0,00 & 3,75 & 10,00 \\
\hline $\mathrm{C} 2$ & 2,50 & 6,25 & 10,00 & 0,00 & 3,75 & 7,50 \\
\hline $\mathrm{C} 3$ & 5,00 & 8,75 & 10,00 & 2,50 & 5,00 & 7,50 \\
\hline $\mathrm{C} 4$ & 2,50 & 6,25 & 10,00 & 2,50 & 5,00 & 7,50 \\
\hline Q1 & 2,50 & 6,25 & 10,00 & 0,00 & 2,50 & 5,00 \\
\hline Q2 & 5,00 & 7,50 & 10,00 & 2,50 & 6,25 & 10,00 \\
\hline Q3 & 5,00 & 8,75 & 10,00 & 0,00 & 2,50 & 7,50 \\
\hline Q4 & 2,50 & 7,50 & 10,00 & 2,50 & 5,00 & 7,50 \\
\hline D1 & 5,00 & 8,75 & 10,00 & 5,00 & 8,75 & 10,00 \\
\hline D2 & 2,50 & 6,25 & 10,00 & 5,00 & 7,50 & 10,00 \\
\hline D3 & 2,50 & 6,25 & 10,00 & 2,50 & 6,25 & 10,00 \\
\hline D4 & 5,00 & 8,75 & 10,00 & 5,00 & 8,75 & 10,00 \\
\hline $\mathrm{F} 1$ & 5,00 & 7,50 & 10,00 & 2,50 & 7,50 & 10,00 \\
\hline $\mathrm{F} 2$ & 2,50 & 6,25 & 10,00 & 5,00 & 7,50 & 10,00 \\
\hline F3 & 0,00 & 6,25 & 10,00 & 2,50 & 5,00 & 7,50 \\
\hline SP1 & 7,50 & 10,00 & 10,00 & 5,00 & 7,50 & 10,00 \\
\hline SP2 & 2,50 & 6,25 & 10,00 & 2,50 & 6,25 & 10,00 \\
\hline SR1 & 2,50 & 7,50 & 10,00 & 5,00 & 7,50 & 10,00 \\
\hline SR2 & 5,00 & 8,75 & 10,00 & 5,00 & 8,75 & 10,00 \\
\hline SR3 & 5,00 & 8,75 & 10,00 & 2,50 & 6,25 & 10,00 \\
\hline SR4 & 2,50 & 5,00 & 7,50 & 2,50 & 6,25 & 10,00 \\
\hline
\end{tabular}

(Source: The Researchers, 2019)

The sixth step of FTOPSIS is to calculate the weight of normalized fuzzy (Vij) by using Equations (15) and (16). Table 18 is the result of the calculation of weight normalized fuzzy calculation. The example is in Equation (17). Then, the same step is done to calculate C2 to SR4 for Supplier A and Supplier B.

$$
\begin{aligned}
& \tilde{V}=\left[\tilde{v}_{\mathrm{ij}}\right]_{\mathrm{m} \times \mathrm{n}} \\
& \tilde{v}_{\mathrm{ij}}=\tilde{x}_{\mathrm{ij}} \times \widetilde{w}_{\mathrm{ij}} \\
& \mathrm{V}_{\mathrm{cl}}(\operatorname{supplier} \mathrm{A})=(0,75 \times 0,50),(1,00 \times 0,88), \\
& (1,00 \times 1,00)=(0,38,0,88,1,00)
\end{aligned}
$$

The sixth step of FTOPSIS is to calculate Fuzzy Positive Ideal Solution (FPIS) (A+) and Fuzzy Negative Ideal Solution (FNIS) (A-) by using Equations (18) and (19). Table 19 is the result of the calculation of FPIS and FNIS. The $\mathrm{A}+\mathrm{C} 1$ is obtained from the largest value (max) of $\mathrm{V}_{\mathrm{Cl}}$ at Supplier A and Supplier B. Then, the A-C1 is from the lowest value (min) of $\mathrm{V}_{\mathrm{Cl}}$ at Supplier A and Supplier B. The $\mathrm{V}_{\mathrm{Cl}}$ of Supplier $\mathrm{A}$ is 0,$38 ; 0,88$; and 1,00 . Moreover, $\mathrm{V}_{\mathrm{Cl}}^{\mathrm{Cl}}$ of
Supplier B is 0,$00 ; 0,38$; and 1,00 . So, $\mathrm{A}+\mathrm{C} 1$ of $1, \mathrm{~m}$, and $\mathrm{u}$ is 0,$38 ; 0,88$; and 1,00 , and $\mathrm{A}-\mathrm{C} 1$ is 0,$00 ; 0,38$; and 1,00 .

$$
\begin{aligned}
& A^{+}=\left\{\tilde{v}_{1}^{+}, \tilde{v}_{\mathrm{j}}^{+}, \ldots, \tilde{v}_{\mathrm{m}}^{+}\right\} \\
& A=\left\{\tilde{v}_{1}^{-}, \tilde{v}_{\mathrm{j}}^{-}, \ldots, \tilde{v}_{\mathrm{m}}^{-}\right\}
\end{aligned}
$$

\begin{tabular}{|c|c|c|c|c|c|c|}
\hline \multicolumn{7}{|c|}{ Normalized fuzzy decision matrix $\left(r_{i j}\right)$} \\
\hline \multirow{2}{*}{ Criteria } & \multicolumn{6}{|c|}{ Supplier } \\
\hline & \multicolumn{3}{|c|}{$\mathbf{A}$} & \multicolumn{3}{|c|}{ B } \\
\hline C1 (benefit) & 0,50 & 0,88 & 1,00 & 0,00 & 0,38 & 1,00 \\
\hline C2 (benefit) & 0,25 & 0,63 & 1,00 & 0,00 & 0,38 & 0,75 \\
\hline $\mathrm{C} 3$ (cost) & 0,50 & 0,29 & 0,25 & 1,00 & 0,50 & 0,33 \\
\hline $\mathrm{C} 4$ (cost) & 1,00 & 0,40 & 0,25 & 1,00 & 0,50 & 0,33 \\
\hline Q1 (benefit) & 0,25 & 0,63 & 1,00 & 0,00 & 0,25 & 0,50 \\
\hline Q2 (cost) & 0,50 & 0,33 & 0,25 & 1,00 & 0,40 & 0,25 \\
\hline Q3 (benefit) & 0,50 & 0,88 & 1,00 & 1,10 & 0,25 & 0,75 \\
\hline Q4 (benefit) & 0,25 & 0,75 & 1,00 & 0,25 & 0,50 & 0,75 \\
\hline $\mathrm{D} 1(\cos \mathrm{t})$ & 1,00 & 0,57 & 0,50 & 1,00 & 0,57 & 0,50 \\
\hline $\mathrm{D} 2(\cos \mathrm{t})$ & 1,00 & 0,40 & 0,25 & 0,50 & 0,33 & 0,25 \\
\hline D3 (benefit) & 0,25 & 0,63 & 1,00 & 0,25 & 0,63 & 1,00 \\
\hline D4 (cost) & 1,00 & 0,57 & 0,50 & 1,00 & 0,57 & 0,50 \\
\hline $\mathrm{F} 1(\cos \mathrm{t})$ & 0,50 & 0,33 & 0,25 & 1,00 & 0,33 & 0,25 \\
\hline $\mathrm{F} 2$ (cost) & 1,00 & 0,40 & 0,25 & 0,50 & 0,33 & 0,14 \\
\hline F3 (benefit) & 0,00 & 0,63 & 1,00 & 0,25 & 0,50 & 0,75 \\
\hline SP1 (benefit) & 0,75 & 1,00 & 1,00 & 0,50 & 0,75 & 1,00 \\
\hline SP2 (benefit) & 0,25 & 0,63 & 1,00 & 0,25 & 0,63 & 1,00 \\
\hline SR1 (cost) & 1,00 & 0,33 & 0,25 & 0,50 & 0,33 & 0,25 \\
\hline SR2 (benefit) & 0,50 & 0,88 & 1,00 & 0,50 & 0,88 & 1,00 \\
\hline SR3 (cost) & 0,50 & 0,29 & 0,25 & 1,00 & 0,40 & 0,25 \\
\hline SR4 (benefit) & 0,25 & 0,50 & 0,75 & 0,25 & 0,63 & 1,00 \\
\hline
\end{tabular}

Table 17 The Result of $r_{i j}$

(Source: The Researchers, 2019)

The seventh step of FTOPSIS is to calculate the distance of $\mathrm{d}+$ and $\mathrm{d}$ - from each alternative by using Equations (20) and (21). Table 20 shows the results of $\mathrm{d}+$ and $\mathrm{d}-$. The $\mathrm{d}+$ can also be interpreted as the distance of a positive ideal solution. Meanwhile, $d+$ is the distance of a negative ideal solution. This step aims to find the range of positive and negative ideal solutions from each sub-criterion.

$$
\begin{aligned}
& d_{\mathrm{i}}^{+}=\sum_{j=1}^{n} d v\left(\tilde{v}_{\mathrm{ij}}, \tilde{v}_{\mathrm{j}}^{+}\right) \\
& d_{\mathrm{i}}^{-}=\sum_{j=1}^{n} d v\left(\tilde{v}_{\mathrm{ij}}, \tilde{v}_{\mathrm{j}}^{-}\right)
\end{aligned}
$$


Table 18 The Results of $\mathrm{V}_{\mathrm{ij}}$

\begin{tabular}{|c|c|c|c|c|c|c|}
\hline \multicolumn{7}{|c|}{$\begin{array}{l}\text { Weight normalized fuzzy } \\
\qquad\left(v_{i j}=r_{i j} \times w_{i j}\right)\end{array}$} \\
\hline \multirow{2}{*}{ Criteria } & \multicolumn{6}{|c|}{ Supplier } \\
\hline & \multicolumn{3}{|c|}{$\mathrm{A}$} & \multicolumn{3}{|c|}{$\mathrm{B}$} \\
\hline $\mathrm{C} 1$ & 0,38 & 0,88 & 1,00 & 0,00 & 0,38 & 1,00 \\
\hline $\mathrm{C} 2$ & 0,06 & 0,39 & 1,00 & 0,00 & 0,23 & 0,75 \\
\hline $\mathrm{C} 3$ & 0,00 & 0,11 & 0,19 & 0,00 & 0,19 & 0,25 \\
\hline $\mathrm{C} 4$ & 0,25 & 0,25 & 0,25 & 0,25 & 0,31 & 0,33 \\
\hline Q1 & 0,19 & 0,63 & 1,00 & 0,00 & 0,25 & 0,50 \\
\hline Q2 & 0,25 & 0,29 & 0,25 & 0,50 & 0,35 & 0,25 \\
\hline Q3 & 0,13 & 0,55 & 1,00 & 0,28 & 0,16 & 0,75 \\
\hline Q4 & 0,06 & 0,38 & 0,75 & 0,06 & 0,25 & 0,56 \\
\hline D1 & 0,50 & 0,50 & 0,50 & 0,50 & 0,50 & 0,50 \\
\hline D2 & 0,50 & 0,30 & 0,25 & 0,25 & 0,25 & 0,25 \\
\hline D3 & 0,06 & 0,31 & 0,75 & 0,06 & 0,31 & 0,75 \\
\hline D4 & 0,50 & 0,50 & 0,50 & 0,50 & 0,50 & 0,50 \\
\hline F1 & 0,25 & 0,29 & 0,25 & 0,50 & 0,29 & 0,25 \\
\hline $\mathrm{F} 2$ & 0,50 & 0,35 & 0,25 & 0,25 & 0,29 & 0,14 \\
\hline F3 & 0,00 & 0,39 & 1,00 & 0,06 & 0,31 & 0,75 \\
\hline SP1 & 0,19 & 0,63 & 1,00 & 0,13 & 0,47 & 1,00 \\
\hline SP2 & 0,06 & 0,47 & 1,00 & 0,06 & 0,47 & 1,00 \\
\hline SR1 & 0,25 & 0,21 & 0,25 & 0,13 & 0,21 & 0,25 \\
\hline SR2 & 0,25 & 0,77 & 1,00 & 0,25 & 0,77 & 1,00 \\
\hline SR3 & 0,25 & 0,21 & 0,25 & 0,50 & 0,30 & 0,25 \\
\hline SR4 & 0,06 & 0,25 & 0,56 & 0,06 & 0,31 & 0,75 \\
\hline
\end{tabular}

(Source: The Researchers, 2019)

Table 19 The Results of FPIS and FNIS

\begin{tabular}{ccccccc}
\hline Criteria & \multicolumn{3}{c}{ A $+=$ Max Vij } & \multicolumn{3}{c}{ A- $=$ Min Vij } \\
\hline C1 & 0,38 & 0,88 & 1,00 & 0,00 & 0,38 & 1,00 \\
C2 & 0,06 & 0,39 & 1,00 & 0,00 & 0,23 & 0,75 \\
C3 & 0,00 & 0,19 & 0,25 & 0,00 & 0,11 & 0,19 \\
C4 & 0,25 & 0,31 & 0,33 & 0,25 & 0,25 & 0,25 \\
Q1 & 0,19 & 0,63 & 1,00 & 0,00 & 0,25 & 0,50 \\
Q2 & 0,50 & 0,35 & 0,25 & 0,25 & 0,29 & 0,25 \\
Q3 & 0,28 & 0,55 & 1,00 & 0,13 & 0,16 & 0,75 \\
Q4 & 0,06 & 0,38 & 0,75 & 0,06 & 0,25 & 0,56 \\
D1 & 0,50 & 0,50 & 0,50 & 0,50 & 0,50 & 0,50 \\
D2 & 0,50 & 0,30 & 0,25 & 0,25 & 0,25 & 0,25 \\
D3 & 0,06 & 0,31 & 0,75 & 0,06 & 0,31 & 0,75 \\
D4 & 0,50 & 0,50 & 0,50 & 0,50 & 0,50 & 0,50 \\
F1 & 0,50 & 0,29 & 0,25 & 0,25 & 0,29 & 0,25 \\
F2 & 0,50 & 0,35 & 0,25 & 0,25 & 0,29 & 0,14 \\
F3 & 0,06 & 0,39 & 1,00 & 0,00 & 0,31 & 0,75 \\
SP1 & 0,19 & 0,63 & 1,00 & 0,13 & 0,47 & 1,00 \\
SP2 & 0,06 & 0,47 & 1,00 & 0,06 & 0,47 & 1,00 \\
SR1 & 0,25 & 0,21 & 0,25 & 0,13 & 0,21 & 0,25
\end{tabular}

Table 19 The Results of FPIS and FNIS (Continued)

\begin{tabular}{ccccccc}
\hline Criteria & \multicolumn{3}{c}{ A+ = Max Vij } & \multicolumn{3}{c}{ A- = Min Vij } \\
\hline SR2 & 0,25 & 0,77 & 1,00 & 0,25 & 0,77 & 1,00 \\
SR3 & 0,50 & 0,30 & 0,25 & 0,25 & 0,21 & 0,25 \\
SR4 & 0,06 & 0,31 & 0,75 & 0,06 & 0,25 & 0,56 \\
\hline
\end{tabular}

(Source: The Researchers, 2019)

Table 20 The Results of d + and d-

\begin{tabular}{ccccc}
\hline \multicolumn{2}{c}{ Distance from each } \\
alternative $=\mathbf{d}+\mathbf{( x , y )}$ & \multicolumn{3}{c}{ Distance from each alternative } \\
Criteria & \multicolumn{4}{c}{ S $+(\mathbf{x}, \mathbf{y})$} \\
& A & B & A lier & B \\
\hline C1 & 0,000 & 0,361 & 0,361 & 0,000 \\
C2 & 0,000 & 0,174 & 0,174 & 0,000 \\
C3 & 0,003 & 0,000 & 0,000 & 0,059 \\
C4 & 0,003 & 0,000 & 0,000 & 0,060 \\
Q1 & 0,000 & 0,377 & 0,377 & 0,000 \\
Q2 & 0,144 & 0,000 & 0,000 & 0,148 \\
Q3 & 0,087 & 0,268 & 0,268 & 0,087 \\
Q4 & 0,000 & 0,130 & 0,130 & 0,000 \\
D1 & 0,000 & 0,000 & 0,000 & 0,000 \\
D2 & 0,000 & 0,147 & 0,147 & 0,000 \\
D3 & 0,000 & 0,000 & 0,000 & 0,000 \\
D4 & 0,000 & 0,000 & 0,000 & 0,000 \\
F1 & 0,144 & 0,000 & 0,000 & 0,144 \\
F2 & 0,000 & 0,162 & 0,162 & 0,000 \\
F3 & 0,036 & 0,151 & 0,151 & 0,036 \\
SP1 & 0,000 & 0,097 & 0,097 & 0,000 \\
SP2 & 0,000 & 0,000 & 0,000 & 0,000 \\
SR1 & 0,000 & 0,072 & 0,072 & 0,000 \\
SR2 & 0,000 & 0,000 & 0,000 & 0,000 \\
SR3 & 0,144 & 0,000 & 0,000 & 0,153 \\
SR4 & 0,007 & 0,000 & 0,000 & 0,114 \\
\hline
\end{tabular}

(Source: The Researchers, 2019)

Table 21 The Results of $\mathrm{CC}_{\mathrm{i}}$ Formulation for Surfactant

\begin{tabular}{ccc}
\hline & \multicolumn{2}{c}{$\mathbf{C C i}\left(\mathbf{d}-/\left(\mathbf{d}-+\mathbf{d}^{*}\right)\right)$} \\
& A & B \\
\cline { 2 - 3 } RANK & 0,773 & 0,292 \\
\hline
\end{tabular}

(Source: The Researchers, 2019) 
Table 22 The Evaluation Status

\begin{tabular}{ll}
\hline Closeness Coefficient $\left(\mathbf{C C}_{\mathbf{i}}\right)$ & Evaluation Status \\
\hline $\mathbf{C C}_{\mathbf{i}} \epsilon[0 ; 0,2]$ & Not recommended \\
$\mathbf{C C}_{\mathbf{i}} \in[0,2 ; 0,4]$ & $\begin{array}{l}\text { Recommended with high } \\
\text { risk }\end{array}$ \\
$\mathbf{C C}_{\mathbf{i}} \in[0,4 ; 0,6]$ & $\begin{array}{l}\text { Recommended with low } \\
\text { risk }\end{array}$ \\
$\mathbf{C C}_{\mathbf{i}} \in[0,6 ; 0,8]$ & Approved \\
$\mathbf{C C}_{\mathbf{i}} \in[0,8 ; 1]$ & Approved and Prefered \\
\hline
\end{tabular}

(Source: The Researchers, 2019)

Based on the steps done, the final result of the FTOPSIS calculation in the supplier selection for surfactant is done. In Table 23 (see Appendices), it can be seen that Supplier A is the first priority with a weight of 0,773 . Thus, the evaluation status is approved. Meanwhile, Supplier B with 0,292 is recommended but with a high risk. It can be said that if the company continues to work with Supplier B, there will be the possibility of inefficiencies and inadequacies that can harm the company. This is inline with glycol and detergent result, which Supplier A become the first priority in Table 23 (see Appendices).

\section{CONCLUSIONS}

According to the results of calculations using the FAHP and FTOPSIS, Supplier A is the first priority with an approved evaluation status. Meanwhile, Supplier B is recommended but with a risk. This conclusion is obtained from the calculation results of the suppliers that have the highest priority order using FAHP method, the shortest distance from the positive ideal solution, and the longest distance from the negative ideal solution using calculations with the FTOPSIS. The calculations using the FTOPSIS have advantages in the form of weight results with a scale of preference recommendations, and they indicate the level of risk to be faced. This method also considers the distance of a positive ideal solution which can provide decisions in maximizing corporate profits. Moreover, FAHP also functions well to identify which priorities should be prioritized in weighting the criteria and subcriteria.

The research concludes that the combination of fuzzy sets theory with MCDM is a suitable approach in supplier selection. It is because the AHP method is very suitable in determining the weighting of criteria and selection of alternative suppliers with priority weighting and TOPSIS in determining supplier alternative selection with a positive ideal solution distance. Then, fuzzy sets get maximum results by eliminating ambiguity and inconsistencies from uncertain criteria and sub-criteria. This approach is very suitable for companies to produce unanimous decisions. Based on that consideration, the research can enrich the body of knowledge to provide additional deficiencies in previous research. It is expected that the future research can be further developed using a combination of rarely found methods.

\section{REFERENCES}

Carter, C. R., Rogers, D. S., \& Choi, T. Y. (2015). Toward the theory of the supply chain. Journal of Supply Chain Management, 51(2), 89-97.

Chatterjee, P., \& Stević, Ž. (2019). A two-phase fuzzy AHP-fuzzy TOPSIS model for supplier evaluation in manufacturing environment. Operational Research in Engineering Sciences: Theory and Applications, 2(1), 72-90.

Chopra, S., \& Meindl, P. (2016). Supply Chain Management: Strategy, planning, and operation. Pearson.

Chen, H. M. W., Chou, S. Y., Luu, Q. D., \& Yu, T. H. K. (2016). A fuzzy MCDM approach for green supplier selection from the economic and environmental aspects. Mathematical Problems in Engineering, 2016, 1-10.

Devi, D. K., \& Wardhana, A. (2018). Analysis and design of the best suppliers selection case study: Department Store Kopetri with the AHP and TOPSIS methods. International Journal of Computer Science and Mobile Computing, 7(6), 109-120.

Gurung, S., \& Phipon, R. (2016). Multi-criteria decision making for supplier selection using AHP and TOPSIS method. International Journal of Engineering Inventions, 6(2), 13-17.

Hajar, Y. A. A. (2016). Using Analytical Hierarchy Process (AHP) to build suppliers' selection model. International Journal of Academic Research in Business and Social Sciences, 6(12), 2222-6990.

Huynh, V. D. B., Nguyen, P. V., Nguyen, Q. L. H. T. T., \& Nguyen, P. T. (2018). Application of Fuzzy Analytical Hierarchy Process based on Geometric Mean Method to prioritize social capital network indicators. International Journal of Advanced Computer Science and Applications, 9(12), 182-186.

Jain, V., Sangaiah, A. K., Sakhuja, S., Thoduka, N., \& Aggarwal, R. (2018). Supplier selection using fuzzy AHP and TOPSIS: A case study in the Indian automotive industry. Neural Computing and Applications, 29(7), 555-564.

Junior, F. R. L., Osiro, L., \& Carpinetti, L. C. R. (2014). A comparison between fuzzy AHP and fuzzy TOPSIS methods to supplier selection. Applied Soft Computing, 21(August), 194-209.

Karabayir, A. N., Botsali, A. R., Kose, Y., \& Cevikcan, E. (2019). Supplier selection in a construction company using fuzzy AHP and fuzzy TOPSIS. In International Conference on Intelligent and Fuzzy Systems (pp. 481-487).

Kementerian Perindustrian Republik Indonesia. (2019). Analisis tahun 2018 perkembangan industri Indonesia. Retrieved from https://kemenperin.go.id/ gpr

Kishore, P., \& Padmanabhan, G. (2016). An integrated approach of fuzzy AHP and fuzzy TOPSIS to select 
logistics service provider. Journal for Manufacturing Science and Production, 16(1), 51-59.

Li, Z., Sun, L., He, L., Tang, X., Zou, X., \& Chen, M. (2019). Distribution network supplier selection with fuzzy AHP and TOPSIS. In $201914^{\text {th }}$ IEEE Conference on Industrial Electronics and Applications (ICIEA) (pp. 62-66).

Lu, J., Zhang, G., Ruan, D., \& Wu, F. (2007). MultiObjective Group Decision Making: Methods, software and applications with Fuzzy set techniques. Imperial College Press.

Mulliner, E., Malys, N., \& Maliene, V. (2016). Comparative analysis of MCDM methods for the assessment of sustainable housing affordability. Omega, 59(March), 146-156.

Nair, A., Jayaram, J., \& Das, A. (2015). Strategic purchasing participation, supplier selection, supplier evaluation and purchasing performance. International Journal of Production Research, 53(20), 6263-6278.

Nazari-Shirkouhi, S., Miri-Nargesi, S., \& Ansarinejad, A. (2017). A fuzzy decision making methodology based on fuzzy AHP and fuzzy TOPSIS with a case study for information systems outsourcing decisions.
Journal of Intelligent \& Fuzzy Systems, 32(6), 39213943.

Ouma, Y. O., Opudo, J., \& Nyambenya, S. (2015). Comparison of fuzzy AHP and fuzzy TOPSIS for road pavement maintenance prioritization: Methodological exposition and case study. Advances in Civil Engineering, 2015, 1-17.

Özbek, A. (2015). Supplier selection with fuzzy TOPSIS. Journal of Economics and Sustainable Development, 6(18), 114-125.

Simić, D., Kovačević, I., Svirčević, V., \& Simić, S. (2017). 50 years of fuzzy set theory and models for supplier assessment and selection: A literature review. Journal of Applied Logic, 24(November), 85-96.

Sultana, I., Ahmed, I., \& Azeem, A. (2015). An integrated approach for multiple criteria supplier selection combining fuzzy Delphi, fuzzy AHP \& fuzzy TOPSIS. Journal of Intelligent \& Fuzzy Systems, 29(4), 1273-1287.

Taylan, O., Bafail, A. O., Abdulaal, R. M., \& Kabli, M. R. (2014). Construction projects selection and risk assessment by fuzzy AHP and fuzzy TOPSIS methodologies. Applied Soft Computing, 17(April), 105-116. 


\section{APPENDICES}

Table 4 Pairwise Comparison between Criteria

\begin{tabular}{lccccccccccccccccccc}
\hline Criteria & \multicolumn{3}{c}{ Cost } & \multicolumn{4}{c}{ Quality } & \multicolumn{3}{c}{ Delivery } & \multicolumn{2}{c}{ Flexibility } & $\begin{array}{c}\text { Supplier } \\
\text { Profile }\end{array}$ & $\begin{array}{c}\text { Supplier } \\
\text { Reputation }\end{array}$ \\
\hline Cost & 1 & 1 & 1 & 6 & 7 & 8 & 1 & 1 & 1 & 8 & 9 & 10 & 1 & 1 & 1 & 1 & 1 & 1 \\
Quality & $1 / 8$ & $1 / 7$ & $1 / 6$ & 1 & 1 & 1 & 4 & 5 & 6 & 8 & 9 & 10 & 8 & 9 & 10 & 8 & 9 & 10 \\
Delivery & 1 & 1 & 1 & $1 / 6$ & $1 / 5$ & $1 / 4$ & 1 & 1 & 1 & 4 & 5 & 6 & 4 & 5 & 6 & 4 & 5 & 6 \\
Flexibility & 0 & $1 / 9$ & $1 / 8$ & 0 & $1 / 9$ & $1 / 8$ & $1 / 6$ & $1 / 5$ & $1 / 4$ & 1 & 1 & 1 & 1 & 1 & 1 & 4 & 5 & 6 \\
Supplier Profile & 1 & 1 & 1 & 0 & $1 / 9$ & $1 / 8$ & $1 / 6$ & $1 / 5$ & $1 / 4$ & 1 & 1 & 1 & 1 & 1 & 1 & $1 / 6$ & $1 / 5$ & $1 / 4$ \\
Supplier Reputation & 1 & 1 & 1 & 0 & $1 / 9$ & $1 / 8$ & $1 / 6$ & $1 / 5$ & $1 / 4$ & $1 / 6$ & $1 / 5$ & $1 / 4$ & 4 & 5 & 6 & 1 & 1 & 1 \\
\hline
\end{tabular}

(Source: The Researchers, 2019)

Table 23 The Result of the Selecting Supplier Using Fuzzy TOPSIS

\begin{tabular}{|c|c|c|c|c|c|c|c|c|c|}
\hline \multirow[b]{2}{*}{ Supplier } & \multicolumn{3}{|c|}{ Surfactant } & \multicolumn{3}{|c|}{ Glycol } & \multicolumn{3}{|c|}{ Detergent } \\
\hline & Weight & Rank & $\begin{array}{l}\text { Evaluation } \\
\text { Status }\end{array}$ & Weight & Rank & $\begin{array}{l}\text { Evaluation } \\
\text { Status }\end{array}$ & Weight & Rank & $\begin{array}{l}\text { Evaluation } \\
\text { Status }\end{array}$ \\
\hline A & 0,773 & 1 & Accepted & 0,623 & 1 & Accepted & 0,628 & 1 & Accepted \\
\hline B & 0,292 & 2 & $\begin{array}{l}\text { Recommended } \\
\text { with high risk }\end{array}$ & 0,595 & 2 & $\begin{array}{l}\text { Recommended } \\
\text { with low risk }\end{array}$ & 0,493 & 2 & $\begin{array}{l}\text { Recommended } \\
\text { with low risk }\end{array}$ \\
\hline
\end{tabular}

(Source: The Researchers, 2019) 